\title{
Prawne instrumenty zarządzania ryzykiem w rolnictwie w nowej Wspólnej Polityce Rolnej
}

1. W czerwcu 2018 r. Komisja Europejska opublikowała propozycje legislacyjne związane z modernizacją i uproszczeniem Wspólnej Polityki Rolnej (WPR) na lata 2021-20271. Choć realizacja poprzedniej już się zakończyła, to podstawowe akty normatywne $\mathrm{w}$ tym zakresie nie zostały jeszcze przyjęte ${ }^{2}$. Niemniej w przedstawionych propozycjach można dostrzec kontynuację poprzedniej WPR, na którą składa się potrzeba realizacji celów gospodarczych W zakresie wzmocnienia odporności rolnictwa, któremu ma towarzyszyć tzw. inteligentny rozwój, a także potrzeba realizacji celów środowiskowo-klimatycznych oraz związanych z rozwojem obszarów wiejskich. Obecnie trwa zatem okres przejściowy i w pewnym zakresie dostosowawczy, który zakończy się 1 stycznia 2023 r.

Przedmiotem artykułu są zagadnienia związane z wdrażaniem nowej Wspólnej Polityki Rolnej, w tym możliwości stosowania prawnych instrumentów zarządzania ryzykiem w rolnictwie. Chodzi głównie o instrumenty, których stosowanie jest obligatoryjne dla państw członkowskich, oraz te, dla których zostało przewidziane szczególne wsparcie. Możliwość ich wykorzystania ma wpływ nie tylko na chęć kontynuowania przez producentów prowadzonej działalności, ale także na stymulowanie rozwoju w oczekiwa-

* Uniwersytet Przyrodniczy w Poznaniu.

${ }^{1}$ Komisja Europejska, Przyszłość wspólnej polityki rolnej, https://ec.europa.eu/info/food-farming-fisheries/key-policies/common-agricultural-policy/future-cap_pl [dostęp: 12.02.2021].

${ }^{2}$ Szerzej: A. Massot, W kierunku wspólnej polityki rolnej po 2020 r., listopad 2020, www. europarl.europa.eu/factsheets/pl [dostęp: 3.02.2020]. 
nym przez prawodawcę kierunku, zbieżnym z założeniami nowej polityki rolnej. Również ograniczenie ryzyka w działalności rolniczej lub podjęcie działań zaradczych w celu minimalizacji jego skutków wpisuje się w niemal każdy z dziewięciu celów przyszłej WPR. Można tu chociażby wspomnieć o wspieraniu godziwych dochodów gospodarstw rolnych i ich odporności w całej Unii w celu zwiększania bezpieczeństwa żywnościowego; zwiększaniu konkurencyjności i wydajności rolnictwa w sposób zrównoważony, aby sprostać wyzwaniom związanym z wyższym popytem w warunkach ograniczonych zasobów i niepewnej sytuacji klimatycznej; poprawie pozycji rolników w łańcuchu wartości; przyczynianiu się do łagodzenia skutków zmian klimatu i przystosowywania się do nich; wydajnym gospodarowaniu glebą; ochronie różnorodności biologicznej czy modernizacji sektora rolnego ${ }^{3}$.

Wybór tej tematyki uzasadnia wiele względów: poznawcze, społeczno-gospodarcze, praktyczne, a także odnoszące się do stanowienia i stosowania prawa. Jeśli chodzi o względy poznawcze, to zagadnienia związane ze stosowaniem prawnych instrumentów zarządzania ryzykiem są rozważane na poziomie unijnym od dwóch dekad. Cały czas podlegają jednak zmianom, co odpowiada zarówno przyjmowanym przez Komisję kierunkom reform rolnych, jak i możliwościom adaptacyjno-regulacyjnym poszczególnych państw członkowskich. Ich swoistość determinuje bowiem rodzaje stosowanych i wspieranych narzędzi.

Jeśli chodzi o względy społeczno-gospodarcze, to stosowane w poszczególnych państwach członkowskich prawne instrumenty zarządzania ryzykiem, którym towarzyszy ustalone przez prawodawcę unijnego wsparcie publiczne, odgrywają istotną rolę w planowaniu działalności rolniczej. Choć kwestia ta jest w dużym stopniu indywidualna i zależna od poszczególnych jednostek wytwórczych (gospodarstw rolnych), to przewidziano w tej mierze instrumenty, które producent może wybrać stosownie do swoich potrzeb i możliwości finansowych, w tym kierunku prowadzonej produkcji oraz związanego z nią ryzyka. Podejmowanie środków zaradczych może mieć wprawdzie ograniczony wpływ na deformację produkcji, jednak niweluje ujemne skutki jej utraty po stronie rolnika.

${ }^{3}$ Uzasadnienie do wniosku Komisji Europejskiej dotyczącego rozporządzenia Parlamentu Europejskiego i Rady ustanawiającego przepisy dotyczące wsparcia na podstawie planów strategicznych sporządzanych przez państwa członkowskie w ramach wspólnej polityki rolnej (planów strategicznych WPR) i finansowanych z Europejskiego Funduszu Rolniczego Gwarancji (EFRG) i z Europejskiego Funduszu Rolnego na rzecz Rozwoju Obszarów Wiejskich (EFRROW) oraz uchylającego rozporządzenie Parlamentu Europejskiego i Rady (UE) nr 1305/2013 i rozporządzenie Parlamentu Europejskiego i Rady (UE) nr 1307/2013, Bruksela, 1.06.2018, COM(2018) 392 final, 2018/0216(COD). 
Omawiane zagadnienia są również istotne ze względów praktycznych. Pomimo rozwoju technologicznego w produkcji rolnej rolnicy wciąż są narażeni na ryzyko, takie chociażby jak duża zmienność dochodów w tym sektorze. Wynika ona po części z oddziaływania sił rynkowych, a w coraz większym stopniu także z ekstremalnych zjawisk pogodowych oraz nasilających się kryzysów sanitarnych i fitosanitarnych. W pewnych sytuacjach duże znaczenie dla prowadzenia produkcji ma również niestabilność regulacyjna, którą można traktować jako ryzyko instytucjonalne. Producent rolny musi bowiem podejmować decyzje gospodarcze $\mathrm{w}$ warunkach zmian legislacyjnych, co nie sprzyja jego aktywności, a nawet ogranicza go ze względu na ich niepewność lub nietrwałość.

Przedstawione względy praktyczne mogą ułatwić proces stanowienia i stosowania prawa w zakresie wdrażania prawnych instrumentów zarządzania ryzykiem, które wiążą się z koniecznością zorientowania WPR na rynek, a zostały ujęte w komunikacie Komisji „Przyszłość produkcji żywności i rolnictwa"4. Chodzi tu zwłaszcza o stworzenie struktur zapewniających zarządzanie ryzykiem, na które powinny składać się nie tylko odpowiednie instrumenty finansowe na potrzeby inwestowania, ale także dostęp do kapitału obrotowego, szkoleń, transferu wiedzy i rzetelnego doradztwa.

Celem rozważań jest udzielenie odpowiedzi na pytanie, czy zaproponowane na poziomie unijnym normy prawne pozwalają na wdrażanie niezbędnych instrumentów prawnych zarządzania ryzykiem w rolnictwie, a także ocena, czy instrumenty te służą wspieraniu producentów rolnych i mogą przyczyniać się do ich ochrony w kontekście przyjętych celów WPR. Według prawodawcy założenia nowej polityki rolnej mają służyć przygotowaniu się do podejmowania przyszłych wyzwań, a zarazem dalszemu wspieraniu żywotnych potrzeb europejskich rolników.

2. Jak wspomniano, nie została jeszcze zakończona procedura ustawodawcza dotycząca WPR po 2020 r. Skutkiem tego jest niemożność przygotowania się państw członkowskich i Komisji do stosowania nowych ram prawnych z 1 stycznia 2021 r. Opóźnienie to wywołało niepewność wśród unijnych rolników i w całym sektorze rolnym co do konstrukcji nowej polityki i proponowanych w niej rozwiązań.

Aby temu zaradzić, prawodawca postanowił, że obowiązujące dotąd akty normatywne będą nadal stosowane, z pewnymi modyfikacjami. Tym samym rozpoczął się okres przejściowy, zdefiniowany w art. 1 rozporządze-

${ }^{4}$ Przyszłość produkcji żywności i rolnictwa - Komunikat w sprawie wspólnej polityki rolnej po 2020 r., Bruksela, 29.11.2017, https://ec.europa.eu/commission/presscorner/detail/pl/ MEMO_17_4842 [dostęp: 30.01.2021]. 
nia Parlamentu Europejskiego i Rady (UE) 2020/2220 z 23 grudnia 2020 r. ustanawiającego niektóre przepisy przejściowe dotyczące wsparcia z Europejskiego Funduszu Rolnego na rzecz Rozwoju Obszarów Wiejskich (EFRROW) i z Europejskiego Funduszu Rolniczego Gwarancji (EFRG) w latach 2021 i 2022 oraz zmieniającego rozporządzenia (UE) nr 1305/2013, (UE) nr 1306/2013 i (UE) nr 1307/2013 w odniesieniu do zasobów i stosowania w latach 2021 i 2022 oraz rozporządzenie (UE) nr 1308/2013 w odniesieniu do zasobów i rozdziału takiego wsparcia na lata 2021 i $2022^{5}$.

Rozporządzenie to utrzymuje, z kilkoma zmianami, w mocy rozwiązania prawne przewidziane w rozporządzeniu Parlamentu Europejskiego i Rady (UE) nr 1305/2013 z 17 grudnia 2013 r. w sprawie wsparcia rozwoju obszarów wiejskich przez Europejski Fundusz Rolny na rzecz Rozwoju Obszarów Wiejskich (EFRROW) i uchylające rozporządzenie Rady (WE) nr 1698/2005 . W akcie tym prawodawca wskazuje na rosnące znaczenie efektywnego zarządzania ryzykiem dla rolników. Z tego względu jego założenia korespondują z koniecznością pomocy rolnikom w rozwiązywaniu problemów wynikających z najczęściej występujących form ryzyka. Przewidziane w rozporządzeniu działania mają pomagać rolnikom w opłacaniu składek na ubezpieczenie plonów, zwierząt i roślin, a także wspierać ich w tworzeniu funduszy wspólnego inwestowania, z których mogą im być wypłacane rekompensaty za straty spowodowane niekorzystnymi zjawiskami klimatycznymi, wystąpieniem chorób zwierząt lub roślin, inwazji szkodników lub incydentów środowiskowych, a także zapewniane wsparcie w sytuacji poważnego spadku dochodów (art. 36 rozporządzenia 1305/2013).

Po zmianie rozporządzenia 1305/2013 na mocy art. 1 pkt 15 rozporządzenia Parlamentu Europejskiego i Rady (UE) 2017/2393 z 13 grudnia 2017 r. zmieniającego rozporządzenia (UE) nr 1305/2013 w sprawie wsparcia rozwoju obszarów wiejskich przez Europejski Fundusz Rolny na rzecz Rozwoju Obszarów Wiejskich (EFRROW), (UE) nr 1306/2013 w sprawie finansowania wspólnej polityki rolnej, zarządzania nią i monitorowania, (UE) nr 1307/2013 ustanawiającego przepisy dotyczące płatności bezpośrednich dla rolników na podstawie systemów wsparcia w ramach wspólnej polityki rolnej, (UE) nr 1308/2013 ustanawiającego wspólną organizację rynków produktów rolnych oraz (UE) nr 652/2014 ustanawiającego przepisy w zakresie zarządzania wydatkami odnoszącymi się do łańcucha żywnościowego, zdrowia zwierząt i dobrostanu zwierząt oraz dotyczącymi zdrowia roślin i materiału przeznaczonego do reprodukcji roślin rekompensata jest

${ }^{5}$ Dz. Urz. UE L 437 z 28.12.2020 r., s. 1-29.

${ }^{6}$ Dz. Urz. UE L 347 z 20.12.2013 r., s. 487-548. 
zapewniana rolnikom ze wszystkich sektorów w przypadku poważnego spadku dochodów ${ }^{7}$.

Wymienione środki stanowią prawne instrumenty zarządzania ryzykiem, dla których przewidziane zostało określone wsparcie na mocy art. 36 rozporządzenia 1305/2013. Udzielane jest ono na umowy ubezpieczenia, które pokrywają straty spowodowane niekorzystnym zjawiskiem klimatycznym, chorobą zwierząt lub roślin, inwazją szkodników lub incydentem środowiskowym bądź straty spowodowane działaniem podjętym zgodnie z dyrektywą 2000/29/WE w celu zwalczenia lub powstrzymania choroby roślin lub inwazji szkodników ${ }^{8}$. Warunkiem jego zastosowania jest strata wynosząca więcej niż 30\% średniej rocznej produkcji rolnika, obliczanej z poprzednich trzech lat lub średniej z trzech lat opartej na okresie pięciu wcześniejszych lat, z wyłączeniem wartości najwyższej i najniższej. Do obliczania rocznej produkcji danego rolnika mogą być stosowane współczynniki (biologiczne lub pogodowe). Istotne jest, aby wystąpienie niekorzystnego zjawiska klimatycznego lub choroby zwierząt lub roślin bądź inwazji szkodników lub incydentu środowiskowego zostało formalnie uznane przez właściwy organ danego państwa członkowskiego według ustalonych wewnętrznie kryteriów.

W odniesieniu do chorób zwierząt rekompensata finansowa na podstawie art. 36 ust. 1 lit. a) rozporządzenia 1305/2013 może być przyznana jedynie w odniesieniu do chorób wymienionych w wykazie chorób zwierząt ustanowionym przez Światową Organizację Zdrowia Zwierząt lub w załączniku do decyzji 2009/470/WE9 .

Aby fundusze wspólnego inwestowania dotyczące niekorzystnych zjawisk klimatycznych, chorób zwierząt i roślin, inwazji szkodników i incydentów środowiskowych mogły kwalifikować się do wsparcia, muszą być akredytowane przez właściwy organ zgodnie z prawem krajowym, prowadzić przejrzystą politykę w kwestii wpłat i wypłat z funduszu oraz mieć jasne zasady podziału odpowiedzialności za długi (art. 37 rozporządzenia 1305/2013). Również w tym przypadku państwa członkowskie określają zasady tworzenia i zarządzania takimi funduszami. Powinny one m.in. zawierać przesłanki przyznawania rekompensat czy kwalifikowania rolników

7 Dz. Urz. UE L 350 z 29.12.2017 r., s. 15-49. To sektorowe narzędzie stabilizacji dochodów, które przyjmuje postać wkładu finansowego, również zapewnia rekompensatę rolnikom z określonego sektora z powodu poważnego spadku dochodów.

${ }^{8}$ Dyrektywa 2000/29/WE z 8 maja 2000 r. w sprawie środków ochronnych przed wprowadzaniem do Wspólnoty organizmów szkodliwych dla roślin lub produktów roślinnych i przed ich rozprzestrzenianiem się we Wspólnocie (Dz. Urz. WE L 169 z 10.07.2000 r.), s. 1.

${ }_{9}$ Decyzja Rady 2009/470/WE z 25 maja 2009 r. w sprawie wydatków w dziedzinie weterynarii (Dz. Urz. WE L 155 z 18.06.2009 r.), s. 30. 
do wsparcia. Początkowo wkład finansowy konieczny do ich ustanowienia był wymagany, aby pokryć koszty administracyjne oraz kwoty wypłacane przez fundusz jako finansowa rekompensata dla rolników. Ponadto mógł być przeznaczany na spłatę odsetek od pożyczek komercyjnych zaciągniętych przez fundusz wspólnego inwestowania w celu wypłaty rolnikom rekompensaty finansowej w przypadku kryzysu. Pierwotnie kapitał podstawowy nie mógł być zasilany z publicznych środków finansowych, ale zakaz ten został zniesiony w efekcie zmiany wprowadzonej na mocy rozporządzenia 2017/2393. Dodatkowo mógł służyć uzupełnianiu rocznych płatności do funduszu. Oba rozwiązania mają zastosowanie także w przypadku instrumentu stabilizacji dochodu.

W przypadku funduszy wzajemnych wsparcie na mocy art. 36 ust. 1 lit. b) rozporządzenia 1305/2013 jest udzielane jedynie na pokrycie strat związanych z wystąpieniem takich samych zjawisk i zdarzeń jak w przypadku ubezpieczeń, o ile został przekroczony próg strat ponad $30 \%$ średniej rocznej produkcji rolnika ustalonego według okresu referencyjnego. Natomiast w odniesieniu do instrumentu stabilizacji wsparcie na mocy art. 36 ust. 1 lit. c) rozporządzenia 1305/2013 przyznawane jest jedynie wtedy, gdy spadek dochodu przekracza 30\% średniego rocznego dochodu indywidualnego rolnika ustalonego według lat referencyjnych. Wartość ta dotyczy wydzielonych na mocy rozporządzenia 2017/2393 narzędzi stabilizacji dochodów dla rolników ze wszystkich sektorów, a w przypadku rolników z określonego sektora - spadek dochodu musi przekraczać próg $20 \%$ (art. 1 pkt 18 i 19).

Płatności z funduszu wspólnego inwestowania na rzecz rolników rekompensują mniej niż 70\% utraconych dochodów w roku, w którym producent zaczyna się kwalifikować do otrzymania tego wsparcia. Jednocześnie, aby możliwe było udzielenie wsparcia, fundusze wspólnego inwestowania muszą a) być akredytowane przez właściwy organ zgodnie z prawem krajowym, b) prowadzić przejrzystą politykę wpłat i wypłat z funduszu, c) mieć przejrzyste zasady podziału odpowiedzialności za długi.

Zasady ich tworzenia ustalają państwa członkowskie, a wkład finansowy, o którym mowa w art. 36 ust. 1 lit. c) rozporządzenia 1305/2013, może dotyczyć jedynie kosztów administracyjnych ustanowienia funduszu wspólnego inwestowania, maksymalnie rozłożonych na okres trzech lat, przy zastosowaniu degresywności, oraz kwot wypłaconych przez fundusz jako finansowa rekompensata dla rolników. Pozostałe kwestie zostały tak samo uregulowane jak w przypadku funduszy wzajemnych.

Jak wspomniano wyżej, wdrożone na mocy rozporządzenia 1305/2013 prawne instrumenty zarządzania wraz z odpowiadającym mu wsparciem obowią- 
zują jeszcze przez dwa lata, do chwili rozpoczęcia realizacji założeń nowej WPR. Jak podkreśla się jednak w preambule do rozporządzenia 2020/2220, aby zachęcić rolników ze wszystkich sektorów do korzystania z nich, prawodawca przewidział możliwość modyfikacji wartości progu strat przez państwa członkowskie (wątek 17). Chodzi tu o obniżenie progu rekompensaty z 30\% do 20\% dla rolników z tytułu spadku produkcji lub dochodów (art. 7 pkt 6-8). Ponadto prawodawca zachęca rolników do oszczędzania w dobrych latach w celu złagodzenia skutków zmienności dochodów.

3. Reforma Wspólnej Polityki Rolnej przewiduje, że do sprawnego wdrażania i realizowania jej celów konieczna jest zmiana podejścia z uniwersalnego na uwzględniające indywidualne potrzeby państw członkowskich. $\mathrm{Z}$ tego powodu każde $\mathrm{z}$ nich zostało zobowiązane do ustanowienia planu strategicznego WPR, obejmującego interwencje w ramach obu filarów: filara I, który obejmuje płatności bezpośrednie i działania sektorowe w zakresie rynków rolnych, oraz filara II, który dotyczy rozwoju obszarów wiejskich. W planie tym państwa członkowskie mają swobodę kształtowania poszczególnych instrumentów interwencji i dostosowywania ich do krajowych uwarunkowań ${ }^{10}$.

Prawodawca zakłada, że taki zindywidualizowany plan przyczyni się do ukierunkowania interwencji w ramach WPR, tak by zmaksymalizować jej wkład w realizację celów UE, a na poziomie państw członkowskich pozwoli na uwzględnienie lokalnych warunków oraz szybszą kontrolę beneficjentów poszczególnych form wsparcia ${ }^{11}$. Plany strategiczne, które mają charakter wieloletni, są opracowywane $\mathrm{w}$ ramach ustrukturyzowanego procesu, a zatwierdza je Komisja ${ }^{12}$.

Warto dodać, że w oparciu o złożone przez Komisję wnioski ustawodawcze państwa członkowskie miały zacząć wdrażać swoje plany strategiczne 1 stycznia 2021 r. Jednak z różnych względów termin ten nie został zachowany i konieczne było ustanowienie okresu przejściowego.

${ }^{10}$ Szerzej: J. Surowiec, Projekt Planu Strategicznego dla Wspólnej Polityki Rolnej, Krajowa Sieć Obszarów Wiejskich, 23.12.2020 r., http://ksow.pl/aktualnosc/projekt-planu-strategicznego-dla-wspolnej-polityki-rolnej [dostęp: 2.03.2020].

${ }^{11}$ Tak: Przyszłość produkcji...

${ }^{12}$ Art. 1 ust. 2 rozporządzenia Parlamentu Europejskiego i Rady UE, COM(2018) 392 wniosek, ustanawiającego przepisy dotyczące wsparcia na podstawie planów strategicznych sporządzanych przez państwa członkowskie w ramach wspólnej polityki rolnej (planów strategicznych WPR) i finansowanych z Europejskiego Funduszu Rolniczego Gwarancji (EFRG) i z Europejskiego Funduszu Rolnego na rzecz Rozwoju Obszarów Wiejskich (EFRROW) oraz uchylającego rozporządzenie Parlamentu Europejskiego i Rady (UE) nr 1305/2013 i rozporządzenie Parlamentu Europejskiego i Rady (UE) nr 1307/2013 - dokument COM(2018)392 final z 1.06.2018 r. 
W preambule omawianego projektu rozporządzenia prawodawca zakłada, że rolnicy ponoszą ostateczną odpowiedzialność za kształtowanie strategii swoich gospodarstw (wątek 15). Niemniej dostrzega potrzebę ustanowienia ram zapewniających zarządzanie ryzykiem. W tym celu państwa członkowskie i rolnicy mogą korzystać z unijnej platformy poświęconej zarządzaniu ryzykiem w celu budowania zdolności, która zapewni im odpowiednie instrumenty finansowe na potrzeby inwestowania oraz dostęp do kapitału obrotowego, szkoleń, transferu wiedzy i poradnictwa ${ }^{13}$.

Szeroko pojęte kwestie zarządzania ryzykiem w rolnictwie zostały zawarte w art. 70. Prawodawca, posługując się wyrażeniem ,narzędzia”, rozumie je jako prawne instrumenty, do stosowania których państwa członkowskie przyznają wsparcie, a które są doprecyzowane w ich planach strategicznych WPR. Państwa członkowskie mogą przyznawać wsparcie przede wszystkim w postaci częściowego finansowania składek w ramach systemów ubezpieczeń oraz funduszy ubezpieczeń wzajemnych, a także pokrycia kosztów administracyjnych ich utworzenia.

Celem przyznawania tego wsparcia, jako przejawu pewnego interwencjonizmu, jest promowanie i upowszechnianie poszczególnych narzędzi zarządzania ryzykiem. Mają one pomagać osobom faktycznie prowadzącym działalność rolniczą w zarządzaniu ryzykiem związanym z produkcją i ryzykiem utraty dochodów w ich działalności rolniczej, będącym poza ich kontrolą ${ }^{14}$. Jednocześnie wsparcie to przyczynia się do osiągnięcia celów szczegółowych WPR określonych w art. 6 projektu rozporządzenia.

Zgodnie z zaproponowanym rozwiązaniem legislacyjnym na państwach członkowskich ciąży obowiązek ustalenia warunków otrzymania wsparcia. Chodzi tu głównie o: a) określenie rodzajów i zakresu ochrony ubezpieczeniowej kwalifikujących się systemów ubezpieczeń i funduszy ubezpieczeń wzajemnych; b) metodę obliczania strat i czynniki uruchamiające odszkodowania; c) ustanowienie przepisów dotyczących tworzenia funduszy ubezpieczeń wzajemnych i zarządzania nimi.

Według art. 70 ust. 5 projektu rozporządzenia państwa członkowskie zapewniają, że wsparcie będzie przyznawane na pokrycie strat wynoszących co najmniej 20\% średniej produkcji rocznej lub średniego rocznego dochodu rolnika z poprzednich trzech lat, lub średniej z trzech lat obliczonej na podstawie pięciu wcześniejszych lat, z wyłączeniem wartości najwyższej i najniższej. Jednocześnie ograniczają wsparcie do maksymalnego poziomu wynoszącego 70\% kosztów kwalifikowalnych. Podobnie jak to było uregu-

13 Tak: Przyszłość produkcji...

${ }_{14}$ W. Rembisz, Kwestie ryzyka, cen, rynku, interwencji i stabilności dochodów w rolnictwie, Warszawa 2013, s. 105. 
lowane w rozporządzeniu 1305/2013, państwa członkowskie zapewniają, że nie wystąpi nadwyżka rekompensaty w wyniku połączenia interwencji na podstawie art. $70 \mathrm{z}$ innymi publicznymi lub prywatnymi systemami zarządzania ryzykiem.

Szczególne podejście prawodawcy można dostrzec w rozwiązaniach zaproponowanych dla sektora wina. Na mocy art. 51 projektu rozporządzenia prawodawca nakłada bowiem na państwa członkowskie konieczność realizacji jednego ze zdefiniowanych celów. Wśród nich wymienia: przyczynianie się do ochrony dochodów unijnych producentów wina w przypadku, gdy ponoszą straty w następstwie klęsk żywiołowych i niekorzystnych zjawisk klimatycznych oraz straty spowodowane przez zwierzęta, choroby lub inwazje agrofagów (art. 51 lit. d) projektu rozporządzenia). W odniesieniu do wskazanych rodzajów ryzyka prawodawca proponuje zastosowanie instrumentu zarządzania, jakim jest ubezpieczenie zbiorów od utraty dochodów w następstwie wskazanych zdarzeń (art. 52 lit. d) projektu rozporządzenia). Unijna pomoc finansowa w tym zakresie nie przekracza 80\% kosztów składek ubezpieczeniowych opłaconych przez producentów w ramach ubezpieczenia od strat powstałych w wyniku niekorzystnych zjawisk klimatycznych porównywalnych do klęski żywiołowej oraz 50\% kosztów składek ubezpieczeniowych opłaconych przez producentów w ramach ubezpieczenia od wskazanych strat klimatycznych oraz od strat spowodowanych przez zwierzęta, choroby roślin lub inwazje agrofagów.

Jak podkreśla prawodawca, pomoc może być przyznana w sytuacji, gdy powyższe wypłaty z ubezpieczenia nie kompensują więcej niż 100\% utraconych przez producentów dochodów, przy uwzględnieniu wszelkich możliwych rekompensat uzyskanych przez producentów w ramach innych programów wsparcia związanych z ubezpieczonym ryzykiem. Umowy ubezpieczenia muszą wymagać od beneficjentów przyjęcia niezbędnych środków zapobiegania ryzyku (art. 53 ust. 4 zd. 2 projektu rozporządzenia).

4. Projekt krajowego Planu Strategicznego dla WPR, który do 14 lutego 2021 r. był przedmiotem konsultacji społecznych, skupia się na konieczności realizacji czterech kluczowych potrzeb: dochodowego rolnictwa, ochrony środowiska i klimatu, bezpiecznej żywności (zdrowego konsumenta) oraz żywotnych obszarów wiejskich ${ }^{15}$. Kwestie zarządzania ryzykiem zostały ujęte w pierwszej potrzebie związanej z permanentnym dysparytetem działalności rolniczej w stosunku do innych działów gospodarki. Przeprowadzona w celu

15 Plan Strategiczny dla Wspólnej Polityki Rolnej - projekt, Ministerstwo Rolnictwa i Rozwoju Wsi, Warszawa, grudzień 2020, s. 20. 
uzasadnienia rozwiązań zaproponowanych w projekcie analiza SWOT wykazała, że tylko 3\% rolników osiąga dochody z działalności rolniczej równe bądź wyższe od przeciętnego rocznego wynagrodzenia w gospodarce narodowej, co nie zachęca do jej prowadzenia. Ponadto coraz częściej występujące gwałtowne i niekorzystne zjawiska przyrodniczo-klimatyczne, a także zmiany na rynkach rolnych będące konsekwencją globalizacji wpływają na wzrost ryzyka dla prowadzących gospodarstwa rolne i dużą zmienność ich dochodów ${ }^{16}$.

Autorzy projektu zwracają uwagę na konieczność zwiększenia liczby rolników korzystających z różnych instrumentów zarządzania ryzykiem, w tym ubezpieczeń ${ }^{17}$. Instrumenty te mają stanowić uzupełnienie instrumentów wsparcia inwestycyjnego dla gospodarstw rolnych. Te ostatnie mają być stosowane w celu realizacji przedsięwzięć, które pozwolą na zapobieganie utracie potencjału produkcyjnego oraz powstawaniu szkód materialnych w wyniku występowania gwałtownych zjawisk pogodowych i chorób. Ponadto aby zwiększyć odporność małych i średnich gospodarstw, udzielane będzie wsparcie w zakresie różnych form współpracy rolników, co zwiększy ich elastyczność i odporność na kryzysy na rynkach rolnych ${ }^{18}$.

Pomoc w ramach Planu Strategicznego dla WPR zostanie ukierunkowana na zapewnienie konkurencyjności i trwałości ekonomicznej podmiotów działających na rynku rolnym głównie poprzez zwiększenie ich zdolności do zapewnienia stabilności, zarówno w krótkiej, jak i w dłuższej perspektywie, z uwzględnieniem rolniczej produkcji towarowej surowców żywnościowych i nieżywnościowych oraz wynagrodzenia za dobra publiczne związane z działalnością rolniczą ${ }^{19}$. Warto podkreślić, że działania w ramach zarządzania ryzykiem $\mathrm{w}$ rolnictwie w celu zwiększenia ochrony dochodów producentów rolnych mają stanowić uzupełnienie podejmowanych przez nich działań zapobiegawczych. To na producentach ciąży zatem wybór właściwych metod zarządzania. W związku z tym w projekcie zostały wymienione i usystematyzowane działania na dwóch poziomach: gospodarstwa i instytucjonalnym.

Najważniejsze dla zarządzania ryzykiem są dopłaty do składek ubezpieczenia upraw rolnych i zwierząt gospodarskich. Ich konstrukcja w odniesieniu do obecnie obowiązującej nie ulega zmianie, przy czym zaproponowany został limit wsparcia na gospodarstwo w wysokości 736 euro, co koreluje ze średnim kosztem dofinansowania jednej umowy ubezpieczenia upraw rolnych z $2018 \mathrm{r}^{20}$

16 Ibidem, s. 21.

17 Według autorów projektu tylko $24 \%$ gospodarstw rolnych korzysta z ubezpieczeń.

18 Plan Strategiczny..., s. 22.

19 Ibidem, s. 21.

${ }^{20}$ Ibidem, s. 120. 
Oprócz wspierania ubezpieczeń przewidywane jest dofinansowanie funduszy ubezpieczeń wzajemnych. Beneficjentem tego wsparcia będzie producent rolny, który jest członkiem takiego funduszu. Wysokość płatności będzie wynikała z minimalnego progu wkładu własnego funduszu. Warunkiem jego uzyskania będzie przedstawienie dowodów utworzenia funduszu, a w kolejnych latach - kwota wypłaconych odszkodowań. Członkowie funduszu są zobligowani do przestrzegania określonych w umowie członkostwa zobowiązań do prowadzenia produkcji rolnej zgodnie $\mathrm{z}$ wymogami agrotechnicznymi ${ }^{21}$. Limit wsparcia dla jednego funduszu ustalono na 2240000 euro.

W ramach interwencji sektorowych szczególne rozwiązania prawne są przewidywane na rynku owoców i warzyw. Projekt rozporządzenia zakłada ich obligatoryjność, a ich dobór powinien zależeć od warunków miejscowych. Sformułowano więc pięć interwencji, które będą mogły być wdrażane w ramach programów operacyjnych organizacji producentów owoców i warzyw w nowej perspektywie finansowej. Na szczególną uwagę wśród nich zasługują działania mające na celu zapobieganie kryzysom oraz zarządzanie kryzysowe na rynku owoców i warzyw (art. 41 b) projektu rozporządzenia o Planach strategicznych WPR). Jego beneficjentami będą organizacje producentów i zrzeszenia organizacji producentów owoców i warzyw, które zostały uznane na podstawie rozporządzenia Parlamentu Europejskiego i Rady (UE) nr 1308/2013 ${ }^{22}$. Celem tej interwencji jest skuteczne zarządzanie ryzykiem na rynku w latach wystąpienia kryzysu oraz pokrycie kosztów kwalifikowalnych związanych m.in. ze wsparciem na usługi doradcze, szkolenia, sprawy techniczne wymiana dobrych praktyk, a zwłaszcza wprowadzenie zrównoważonych metod ograniczania występowania szkodników, zrównoważone wykorzystanie środków ochrony roślin, jak również wykorzystanie platform sprzedażowych, giełd towarowych typu spot i terminowych ${ }^{23}$.

5. Zmienność środowiska przyrodniczego, gospodarczego i politycznego stawia przed rolnikami nowe wyzwania. Nie pozostają oni obojętni na zmiany klimatu, niestabilność cen czy niepewną sytuację legislacyjną. Wymaga to od nich wysiłku adaptacyjnego, w tym szybkiego reagowania na poszczególne zmienne i dokonywania właściwych wyborów produkcyjnych. Obowiązkiem ustawodawcy jest zaś pomaganie im w radzeniu sobie ze zmianami oraz tworzenie przepisów prawnych, kształtujących m.in. prawne instrumenty

${ }^{21}$ Ibidem, s. 121.

22 Rozporządzenie Parlamentu Europejskiego i Rady (UE) nr 1308/2013 z 17 grudnia 2013 r. ustanawiające wspólną organizację rynków produktów rolnych oraz uchylające rozporządzenia Rady (EWG) nr 922/72, (EWG) nr 234/79, (WE) nr 1037/2001 i (WE) nr 1234/2007 (Dz. Urz. UE L 347 z 20.12.2013 r.), s. 671-854.

${ }^{23}$ Plan Strategiczny..., s. 84. 
zarządzania ryzykiem w dłuższej perspektywie czasu, sprzyjających ochronie przed jego negatywnymi skutkami.

Jeżeli chodzi o dotowane instrumenty zarządzania ryzykiem, to należy pozytywnie ocenić zaproponowane warunki ich stosowania i kompetencje państw członkowskich w tym zakresie. Powinny one pozwolić na równe traktowanie rolników w całej Unii, nie prowadząc do zakłóceń konkurencji na rynku ani wypełniania zobowiązań międzynarodowych Unii.

Ustalony model wdrażania WPR, zorientowany na wyniki i pomocniczość, może przyczynić się do upowszechnienia poszczególnych prawnych instrumentów zarządzania ryzykiem. Zaraz po producencie rolnym duże znaczenie przypisano państwom członkowskim, czyniąc je jednocześnie odpowiedzialnymi za stosowanie polityki interwencyjnej w rolnictwie.

Analizując instrumenty zarządzania ryzykiem w projektowanym rozporządzeniu, można od razu dostrzec ich zubożenie. Prawodawca pominął bowiem w nim instrument stabilizacji dochodu. To uszczuplenie jest jednak zafałszowane, ponieważ kategoria funduszy wzajemnych obejmuje zarówno fundusze związane ze stratami produkcyjnymi, jak i ogólne oraz specyficzne dla danego sektora narzędzia stabilizacji dochodów związane $\mathrm{z}$ utraconymi dochodami. Również w takim ujęciu instrumenty te funkcjonowały w ramach WPR 2014-2020, a ich działanie było oparte na zasadach właściwych dla funduszy wzajemnych. Przy czym teoretycznie różniły się one przedmiotem ochrony. W regulacji unijnej można też zauważyć pewne jej uproszczenie.

Jeśli chodzi o projekt rodzimego planu, to odpowiada on założeniom WPR. Przewidziane w nim działania są ukierunkowane przede wszystkim na wspieranie ubezpieczeń upraw rolnych i zwierząt gospodarskich na zasadach dotychczas stosowanych. Wskazuje na to chociażby zaproponowana wysokość wsparcia na gospodarstwo, która została ustalona według danych historycznych. Można sądzić, że ubezpieczenie jako podstawowy instrument zarządzania ryzykiem nadal będzie wykorzystywany w niewielkim zakresie.

Z kolei jeśli chodzi o fundusze wzajemne, to wyraźnie zabrakło w projekcie rozwiązania normatywnego dotyczącego mechanizmu rekompensującego rolnikom niskie ceny za produkty, jako instrumentu stabilizacji cen. Ponadto przy projektowaniu wsparcia dla funkcjonowania funduszy wzajemnych zabrakło podstaw prawnych do ich tworzenia w kraju. Tego rodzaju wsparcie nie znajdzie zatem beneficjentów.

Krajowy ustawodawca stoi zatem przed wyzwaniem zbudowania sprawnego systemu ubezpieczeniowego, obejmującego zarówno ubezpieczenia majątkowe rolnicze, jak i nowatorskie ubezpieczenia dochodu rolniczego. Będzie to jednak wymagało ograniczania stosowanej do tej pory pomocy ad hoc. 


\title{
BIBLIOGRAFIA
}

Massot A. (2020), W kierunku wspólnej polityki rolnej po 2020 r., www.europarl.europa.eu/ factsheets/pl [dostęp: 3.02.2020].

Rembisz W. (2013), Kwestie ryzyka, cen, rynku, interwencji i stabilności dochodów w rolnictwie, Warszawa.

Surowiec J. (2020), Projekt Planu Strategicznego dla Wspólnej Polityki Rolnej, Krajowa Sieć Obszarów Wiejskich, 23.12.2020 r., http://ksow.pl/aktualnosc/projekt-planu-strategicznego-dla-wspolnej-polityki-rolnej [dostęp: 2.03.2020].

\section{LEGAL INSTRUMENTS FOR RISK MANAGEMENT IN AGRICULTURE IN THE NEW COMMON AGRICULTURAL POLICY}

\section{Summary}

The subject of the article is issues related to risk management in agriculture that may arise in connection with the implementation of the new Common Agricultural Policy. The question to answer is whether the regulations proposed at the EU level make the implementation of the necessary legal instruments possible and whether these instruments support agricultural producers and contribute to their protection in the aspect of the priorities of the CAP. The findings of the research conducted allow to assess the proposed legal solutions positively. The EU model of CAP implementation, based on the subsidiary principle and result-oriented, may contribute to a wider application of particular legal instruments of risk management. The legal solutions proposed in Poland correspond to the assumptions of the CAP. However, it seems that insurance as a basic management instrument will continue to be used insufficiently. The lack of legal regulations concerning the creation of mutual funds is still a weakness when it comes to the approach to the Polish model of risk management.

Keywords: Common Agricultural Policy, risk management in agriculture, agricultural producers, insurance in agriculture

\section{STRUMENTI GIURIDICI DI GESTIONE DEL RISCHIO IN AGRICOLTURA SECONDO LA NUOVA POLITICA AGRICOLA COMUNE}

\author{
Riassunto
}

L'articolo si concentra sulla nuova Politica Agricola Comune, nello specifico sulla gestione del rischio in agricoltura. L'obiettivo è quello di rispondere alla domanda se le regolazioni proposte a livello dell'UE possano permettere di attuare gli strumenti giuridici necessari, e quindi di sostenere i produttori agricoli, contribuendo a tutelarli alla luce delle priorità esposte nella PAC. L'analisi svolta permette di dare una valutazione positiva circa le soluzioni giuridiche proposte. Bisogna dire che il modello dell'UE, già consolidato nell'attuare la PAC e orientato ai risultati e alla sussidiarietà, può contribuire a far diffondere alcuni 
specifici strumenti giuridici di gestione del rischio. Le soluzioni giuridiche proposte in Polonia rispecchiano i presupposti della PAC. Tuttavia, sembra che la scelta di gestire il rischio tramite lo strumento delle assicurazioni continuerà ad essere marginale. Il modello nostrano ha un punto debole: mancano le regolazioni giuridiche riguardanti i fondi comuni di investimento.

Parole chiave: Politica Agricola Comune, gestione del rischio in agricoltura, produttori agricoli, assicurazioni in agricoltura 